\title{
ANALISIS FAKTOR-FAKTOR SENSORY MARKETING PADA MASKAPAI PENERBANGAN \\ (Survei pada Wisatawan Mancanegara yang Pernah Menggunakan The World's 4 Star Airlines di Bandara Internasional Soekarno-Hatta)
}

\author{
Mochamad Eri Nugraha \\ HP. Diyah Setiyorini \\ Manajemen Pemasaran Pariwisata FPIPS UPI
}

\begin{abstract}
Tourism is an integral part of human life. The sector is growing as it has become a necessity for leisure travelers along with the development of the sociocultures undergoing changes. One of the tourism industries that always increases its growth is the airline industry. As stated in the background above, the author conducted a research on The World's 4 Star Airlines in Asia-Pacific and Southeast Asia. In the study, the author took the title: The Analysis of Sensory Factors in Airline Marketing. The purpose of the study was to obtain results of the confirmatory analysis of the most dominant sensory dimension of marketing The World's 4 Star Airlines at Soekarno-Hatta International Airport. This research was descriptive and verificative, and the method of the research was a descriptive survey and explanatory survey. The samples taken in this study were as many as 100 people from the population of 1.195 .596 foreign tourist passengers. The technique of sampling done by the author was a systematic sampling. Data processing was done by using the statistical test through SPSS 20.0 for Windows and AMOS 5. The results showed that the sensory dimension of marketing that was the most dominant was the dimension of sight which was equal to 21:36\%. Whereas the most dominant sensory marketing indicator was equal to 10:07\%.
\end{abstract}

Keywords: sensory marketing, confirmatory factor analysis

\section{PENDAHULUAN}

\subsection{Latar Belakang}

Pariwisata merupakan bagian yang tidak terpisahkan dari kehidupan manusia. Menurut dewan perjalanan dan pariwisata dunia World Travel and Tourism Council (WTTC), saat ini pariwisata termasuk ke dalam kelompok industri terbesar dunia (the world's largest industry). Devisa suatu negara dihasilkan dari kedatangan wisatawan mancanegara ke negara tujuan, fakta menyebutkan bahwa kegiatan pariwisata dengan menggunakan transportasi telah menghasilkan pendapatan yang mencapai US\$ 1 Triliun, dan US\$ 3 Juta per hari pada tahun 2009 (UN-WTO Highlight 2010). Hal ini sesuai dengan pendapatan pariwisata sebagai top 5 export di negara UN-WTO, $38 \%$ sebagai sumber utama devisa di Asia Tenggara.

Industri penerbangan di Indonesia telah mengalami pertumbuhan secara positif seperti yang terjadi di beberapa negara di seluruh dunia, sehingga hal ini menyebabkan industri penerbangan masuk ke dalam lima industri terbesar dengan market size yang cukup berperan terhadap pendapatan dari sektor industri di Indonesia. Dapat dilihat Tabel 1.2 market size industri penerbangan pada tahun 2010 di bawah ini. 
TABEL 1.2

PERKIRAAN PERTUMBUHAN MARKET SIZE BEBERAPA SEKTOR INDUSTRI TAHUN 2010

\begin{tabular}{|c|c|c|c|c|c|c|c|c|c|}
\hline NO & SEKTOR & $\begin{array}{l}2007 \\
\text { Nominal }\end{array}$ & $\%$ & $\begin{array}{l}2008 \\
\text { Nominal }\end{array}$ & $\%$ & $\begin{array}{l}2009 \\
\text { Nominal }\end{array}$ & $\%$ & $\begin{array}{l}2010 \\
\text { Nominal }\end{array}$ & $\%$ \\
\hline 1 & Penerbangan(PDB, Rp miliar) & $16.592,0$ & 3,1 & $20.937,6$ & 6,2 & $24.604,0$ & 7,5 & $27.598,8$ & 8,3 \\
\hline 2 & Biro Perjalaan (PDB, Rp miliar) & $26.148,1$ & 5,1 & $32.335,9$ & 3,7 & $37.272,2$ & 5,3 & $34.567,2$ & 5,5 \\
\hline 3 & Hotel (PDB, Rp miliar) & $17.431,7$ & 8,4 & $21.602,4$ & 3,9 & $24.952,7$ & 5,5 & $29.543,0$ & 6,1 \\
\hline 4 & $\begin{array}{l}\text { Restoran dan fastfood (PDB, Rp } \\
\text { miliar) }\end{array}$ & $105.600,2$ & 14,3 & $137.363,1$ & 0,1 & $166.544,0$ & 1,2 & $167.897,5$ & 1,4 \\
\hline
\end{tabular}

Sumber: Danareksa Research Institute - SWA NO. 27/XXIV/18 Desember 2009.

Tabel 1.2 menyebutkan industri penerbangan diperkirakan mengalami kenaikan pertumbuhannya yaitu dari 7,5\% pada tahun 2009 , menjadi $8,3 \%$ pada tahun 2010 (meningkat $0.8 \%$ ).

Hal ini dapat berpengaruh terhadap jumlah penumpang wisatawan mancanegara yang datang ke Indonesia melalui Bandara Soekarno-Hatta yang dapat di lihat pada Gambar 1.2 di bawah ini.

\section{Wisman ke BISH}

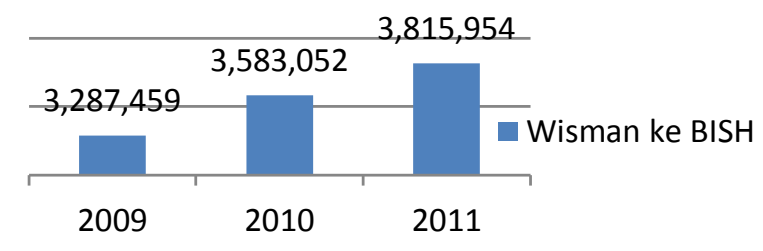

Sumber: PT (Persero) Angkasa Pura I dan II, 2012.

GAMBAR 1.2

JUMLAH KEDATANGAN PENUMPANG

WISATAWAN MANCANEGARA DI

BANDARA SOEKARNO-HATTA

DARI TAHUN 2009-2011

Gambar 1.2 menyebutkan jumlah penumpang wisatawan mancanegara yang datang ke Indonesia melalui Bandara Soekarno-Hatta sebanyak 3.815.954 di tahun 2011, meningkat sebanyak 232.902 wisatawan mancanegara atau naik sebesar $3.14 \%$ dibandingkan dengan jumlah kedatangan penumpang wisatawan mancanegara di tahun 2010.

The World's 4 Star Airlines memiliki misi-misi yang di dalamnya terdapat strategi untuk dapat memberikan pelayanan yang terbaik terhadap pelanggan, hal ini dikarenakan ke enam maskapai tersebut di atas sangat menyadari bahwa kepuasan pelanggan merupakan kunci kesuksesan bagi perusahaan. Berikut Gambar 1.3 di bawah ini customer satisfaction index yang diperoleh The World's 4 Star pada tahun 2011.

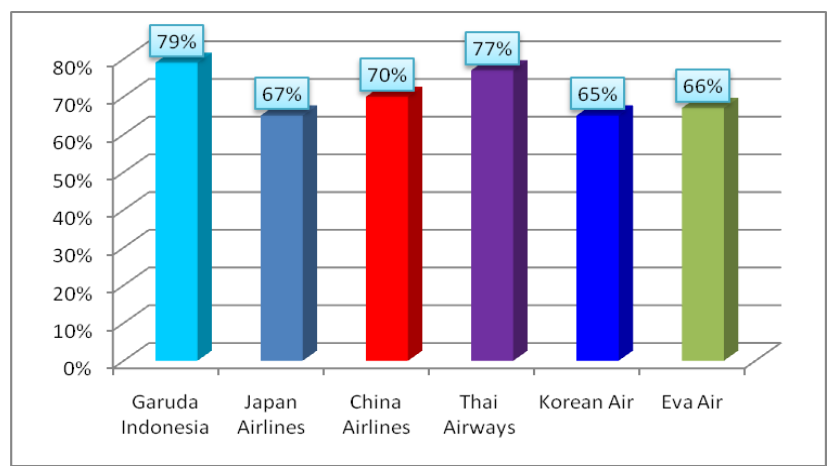

Sumber: $w w w$. airlinequality.com (Diakses dari internet pada tanggal 30 April 2011).

\section{GAMBAR 1.3}

CUSTOMER SATISFACTION INDEX THE WORLD'S

\section{STAR AIRLINES TAHUN 2011}

Berdasarkan Gambar 1.3 di atas The World's 4 Star Airlines telah mendapatkan persentase dalam kategori memuaskan karena telah melebihi passing grade di atas 60\% menurut ukuran internasional. (www.airlinequality.com) diakses dari internet pada tanggal 20 Maret 2011.

Mustafa, Pei, Peng, \& Hamid (2005:1) mengatakan bahwa "Competition on the air travel industry is very fierce", untuk itu persaingan di industri penerbangan dalam memberikan atraksi yang sensasional kepada 
pelanggan tidaklah mudah, karena setiap maskapai harus bersaing baik dalam satu aliansi maupun berbeda aliansi, sehingga apabila passing grade kepuasan pelanggan yang dimiliki The World's 4 Star Airlines turun di bawah angka 60\%, status maskapai 4 Star Airlines tersebut akan turun menjadi 3 Star Airlines. Dengan demikian akan berdampak pada kurangnya kepercayaan penumpang, pendapatan yang diperoleh maskapai, dan image dari maskapai tersebut.

Oliver dalam Valerie A. Zeithaml (2009:104) berpendapat bahwa "Satisfaction is the customer's fulfillment response" artinya, kepuasan adalah memenuhi segala kebutuhan pelanggan. Shaw (2007:15) mengatakan bahwa:

"It is hoped that enough has now been said to show that correctly identifying and targeting "Customers" rather than mere "Consumers" is a cornerstone of successful marketing in the airline industry.

Thai Airways mencoba menjawab pernyataan tersebut diatas dengan beberapa strategi-strategi seperti promotional program, meningkatkan service quality dengan menambah armada baru dengan seat dan inflight entertainment untuk tujuan dapat memberikan kenyamanan yang lebih terhadap pelanggan secara jangka panjang dan dapat bersaing dalam kompetisi di airline industry. Thai Airways tidak melupakan untuk memperhatikan nilai pelanggan, dan sebagai ujung tombaknya adalah employee (karyawan) yang melayani pelanggan sampai dengan level tertinggi untuk memastikan bahwa kepuasan didapatkan setiap pelanggan dengan customer oriented culture.(sumber: annual report Thai Airways 2011).

Garuda Indonesia memiliki strategi dengan marketing communication dan perluasan jalur distribusi, dengan tujuan meningkatkan brand awareness dan persepsi masyarakat internasional terhadap Garuda Indonesia. Garuda Indonesia menyediakan armada terbaru dengan meningkatkan fasilitas inflight entertainment, penggunaan ornamen khas Indonesia, wewangian khas Indonesia, musik khas Indonesia, dan cita rasa khas Indonesia, serta kualitas pelayanan dengan konsep keramahtamahan khas Indonesia dengan tujuan mempromosikan Indonesia kepada dunia.(sumber: annual report Garuda Indonesia 2011).
Japan Airlines mengalami kebangkrutan pada tahun 2010, faktor penyebab utama kebangkrutan Japan Airlines adalah financial crisis yang menyebabkan Japan Airlines memiliki hutang hampir 500 Milyar Yen (sumber: www.suaramedia.com/diakses pada 30 Juni 2011). Kebangkrutan tersebut membuat Japan Airlines tetap ingin mempertahankan eksistensinya di industri penerbangan dengan restrukturisasi besarbesaran yang salah satunya mengurangi pesawat berbadan besar dan menggantinya dengan pesawat terbaru dengan fasilitas dan konsep pelayanan yang lebih ditingkatkan dengan tujuan agar pelanggan tetap menggunakan Japan Airlines. Pesawat yang baru dengan fasilitas dan amenitas baru, serta pelayanan yang lebih ditingkatkan diharapkan Japan Airlines mendapatkan profit setelah mengalami kebangkrutan pada tahun 2010 (sumber: Websites Japan Airlines 2011).

China Airlines memperkenalkan "Five Movements" yaitu kekuatan perusahaan dengan fokus terhadap lima aspek yang paling penting termasuk safety, marketing, public relations, environmental protection, and service. Kelima aspek tersebut pelanggan akan merasakan dan mengerti produk dan metode yang diberikan perusahaan, sehingga akan meningkatkan pelayanan karyawan yang implikasinya akan dapat memberikan kepuasan kepada pelanggan.(sumber: annual report China Airlines 2011).

Eva Air berdedikasi dalam safety dan service quality, dengan filosofi perusahaan memberikan keamanan secara nyata, kenyamanan dan bersahabat, serta, pelayanan yang comprehensive. Eva Air secara konsisten mempertahankan rekor catatan keselamatan dengan menghadirkan pesawat-pesawat yang berumur muda demi penghematan menghemat bahan bakar yang harganya terus naik, sehingga pendapatan perusahaan dapat maksimal demi melayani kenyamanan pelanggan. Kabin diterapkan suguhan state-ofthe-art cabin, selain itu amenitas dan fasilitas kabin diperbaharui agar pelanggan merasa nyaman dan puas.(sumber: annual report Eva Air 2011).

Korean Air memiliki beberapa strategi yang tertuang di dalam character ethic's yang salah satu isinya adalah "We regard customer satisfaction and safety as our highest priority". Character Ethics tersebut merupakan 
komitmen Korean Air dalam kepuasan pelanggan dan keamanan, selain itu armada pesawat terus diperbaharui demi kenyamanan, fasilitas terbaru yang menuguhkan berbagai fasilitas yang menunjang segala kebutuhan pelanggan .(sumber: annual report Korean Air 2011)

Disimpulkan bahwa The World's 4 Star Airlines dalam upaya-nya mempertahankan pelanggan melalui program-program seperti safety flight, ,promotional program, reduce future personel expenses, proactive fuel management, cabin improvement, improvement company culture, pricing strategy, strong alliance member, customer oriented cultur, dan powerfull service quality sehingga penumpang dapat merasakan pengalaman yang disuguhkan seperti menikmati aesthetic, kemenarikan, kecantikan, dan sensory stimulation The World's 4 Star Airlines sesuai dengan yang dikemukakan oleh Schmitt (1999:127)

Menyikapi kondisi ekonomi global tentang kenaikan bahan bakar pesawat, maka dari itu The World's 4 Star Airlines menghadirkan pesawat terbaru mereka dengan perhitungan dengan menggunakan pesawat baru ditambah dengan fasilitas dan amenitas baru yang dapat meningkatkan rasa aman dan nyaman kepada pelanggan, disamping memberikan pendapatan yang maksimal bagi The World's 4 Star Airlines, dan salah satu strategi agar pelanggan merasa puas menggunakan pesawat maka The Worlds 4 Star Airlines menggunakan strategi sensory marketing.

Strategi sensory marketing dalam pelaksanaannya diperlukan hal-hal sensasional, seperti halnya terdapat bar di dalam kabin pesawat dan inovatif agar dapat dirasakan oleh panca indera sehingga dapat memberikan kepuasan pelanggan. Sependapat dengan Aradhna Khrisna dalam Journal of Marketing Research (2008:18) yang mengemukakan bahwa, creating sensory marketing trough innovative sensory variation across five senses able to attract customer satisfaction and loyalty moreover.

Kutipan tersebut menjelaskan bahwa menerapkan sensory marketing dengan variasi sensory yang inovatif melalui lima panca indera akan mampu memberikan kepuasan , rasa nyaman dan loyalitas yang lebih. Oleh karena itu The World's 4 Star Airlines melakukan strategi melalui faktor-faktor sensory marketing. Solomon (2011:83) menyebutkan bahwa terdapat lima dimensi dalam sensory marketing yaitu sight, sounds, smells, taste, dan textures/touch.

Masing-masing maskapai penerbangan memiliki kelemahan dan keunggulan dalam dimensi strategi sensory marketing. Garuda Indonesia unggul di semua dimensi dengan rata-rata mendapatkan rating 4 stars. Japan Airlines memiliki kelemahan dalam dimensi sight, sounds, dan taste yang mendapatkan rating 3 star akan tetapi unggul dalam dimensi smells \& textures dengan rating 4 stars. China Airlines memiliki kelemahan dalam dimensi sounds yang mendapatkan rating 3 stars, akan tetapi dimensi sight, smells, taste, dan textures mendapatkan rating 4 stars dalam inflight. Thai Airways memiliki rating 4 stars di semua dimensi, namun dalam dimensi textures Thai Airways mendapatkan rating 5 stars inflight yang artinya memiliki nilai sekelas 5 Star Airlines. Korean Air memiliki keunggulan dalam dimensi sight, dan textures untuk inflight. Eva Airways memiliki kelemahan di semua dimensi untuk, sedangkan inflight Eva Airways unggul dalam hampir di semua dimensi dengan rating 4 stars, kecuali dalam dimensi sounds hanya mendapatkan rating 3 stars. (diakses dari berbagai sumber pada tanggal 20 Mei 2011).

Sensory marketing yang dilakukan The World's 4 Star Airlines digunakan untuk menciptakan sensasi terhadap penumpangnya guna memenuhi kebutuhan dan keinginan penumpang yang diharapkan dapat memberikan pelayanan terbaik melalui faktorfaktor yang digunakannya, sehingga akan memberikan benefit secara jangka panjang. Berdasarkan latar belakang di atas perlu dilakukan penelitian tentang "Analisis FaktorFaktor Sensory Marketing Pada Maskapai Penerbangan”.

\subsection{Rumusan Masalah}

Berdasarkan latar belakang di atas, maka dapat dirumuskan permasalahan pokok dalam penelitian ini adalah:

1. Bagaimana gambaran sensory marketing yang terdiri dari sight, sounds, smells, taste, dan touch/textures The World's 4 Star Airlines. 
2. Faktor-faktor apa yang paling dominan dalam pembentukkan sensory marketing yang terdiri dari sight, sounds, smells, taste, dan touch/textures the world's 4 star airlines.

\subsection{Tujuan Penelitian.}

Berdasarkan pada pokok permasalahan yang telah di uraikan di atas, maka penelitian ini bertujuan:

1. Untuk memperoleh hasil temuan mengenai analisis konfirmatori yang paling dominan dari dimensi sensory marketing pada maskapai the world's 4 star airlines di Bandara SoekarnoHatta.

2. Untuk memperoleh hasil temuan mengenai analisis konfirmatori yang paling dominan dari indikator sensory marketing the world's 4 star airlines di Bandara Soekarno-Hatta.

\subsection{Kegunaan Penelitian.}

1. Kegunaan Teoritis

Hasil penelitian ini diharapkan dapat memberikan tambahan pengetahuan dan memperluas khasanah mengenai ilmu-ilmu marketing khususnya sensory marketing yang terdiri dari sight, smells, sounds, taste, dan touch/textures.

2. Kegunaan Praktis

Hasil penelitian ini dapat memberikan masukan kepada pihak maskapai the world's 4 star airlines dalam hal ilmu marketing khususnya sensory marketing agar dapat memberikan produk atau jasa atraktif dan sensasional dalam memberikan pelayanan kepada penumpang.

\section{KERANGKA PEMIKIRAN DAN HIPOTESIS}

\subsection{Kerangka Pemikiran}

Industri penerbangan telah menjadi industri yang bersifat global dan berkembang sekian lama sehingga telah mengalami persaingan yang sangat kompetitif. Keadaan yang seperti ini, maka para pemasar industri penerbangan dituntut untuk kreatif, inovatif, dan sensasional dalam melakukan aktivitas pemasaran.
Smilansky (2009:13) mengatakan bahwa, experiential marketing adalah suatu proses mengidentifikasi dan memberikan kebutuhan pelanggan dan aspirasi pelanggan. Pengalaman merupakan emotional benefit yang ditawarkan lembaga sesuai dengan kebutuhan konsumen kadang-kadang kesan emosional benefit menjadi ciri khas bagi suatu lembaga, yang sulit ditiru lembaga lain. Sedangkan menurut Fransisca Andreani (2007:1) experiential marketing merupakan sebuah pendekatan untuk memberikan informasi yang lebih dari sekedar informasi mengenai sebuah produk atau jasa.

Smilansky (2009:9) menyebutkan bahwa perubahan pandangan dari pesan rasional menjadi pesan emosional atau kombinasi dari keduanya. Kemudian Solomon (2011:83) menyebutkan bahwa sensasi adalah cepatnya penerimaan (receptors) oleh panca indera yang dimiliki (seperti mata, telinga, hidung, mulut, dan jari) untuk memberikan rangsangan terhadap cahaya, warna, suara, wewangian, dan bentuk.

Sensory marketing di berbagai penelitian digunakan agar setiap perusahaan lebih sukses dan pengalaman sensory dapat lebih dirasakan pelanggan. Studi mengenai sensory marketing pada saat ini telah mengalami perkembangan dengan begitu pesat. Peralihan dari traditional marketing yang terlalu mengacu kepada hal yang rasional, dengan sensory marketing ide pemasaran traditional marketing telah beralih ke arah emotional marketing. Kotler dalam Halmstald (2009:9) menyebutkan bahwa kreasi dari pembangunan lingkungan dapat menyebabkan faktor emosional secara spesifik dan memberikan efek terhadap seseorang, seperti waktu luang dan kemenarikan tempat akan menambah kemungkinan dalam melakukan pembelian.

Laurie Babin dalam Journal of Advertising (2010:5) menyebutkan "The potential of imagery is both potent and provocative, especially when one takes into account that the forms of mental impressions include all five senses". Aradhna Khrisna (2009:5) mengatakan bahwa aspek dari produk harus meliputi touch, taste, smells, sounds, dan produk yang terlihat, mempengaruhi emosi, persepsi, pilihan, dan konsumsi dari produk. Hulten, Broweus, dan Van Dijk (2009:2) menyebutkan bahwa sensory marketing berkembang secara cepat dalam lingkungan 
pemasaran, melalui lima panca indera (seperti penglihatan, suara, wewangian, rasa, dan sentuhan).

Berbagai penelitian mengenai dimensi sensory marketing telah dilakukan oleh para ahli dari berbagai latar belakang yang berbeda pula. Hasil penelitian tersebut menyebabkan pendapat yang bervariasi dalam dimensi yang dapat mempengaruhi perilaku konsumen terhadap suatu produk atau jasa Kahn (2007:3) dalam penelitiannya menyebutkan bahwa terdapat 5 panca indera manusia yang dapat terhubung dengan sebuah produk (brand) yaitu sight, sounds, smells, taste, dan touch. Kahn berpendapat bahwa dimensi sight memiliki pengaruh yang kuat terhadap emosi pelanggan. Hulten, Broweus, dan Van Dijk (2009:89-134) memiliki pandangan berbeda dengan pendapat Kahn. Hulten, Broweus, dan Van dijk berpendapat ke-lima dimensi sensory marketing dapat berpengaruh terhadap pengalaman yang dapat memuaskan pelanggan.

Halmstald (2009:10-15) yang berlatar belakang food industry menyebutkan bahwa sensory marketing dapat berpengaruh terhadap tingkat penjualan. Halmstald menyebutkan 5 dimensi sensory marketing dengan visual, sonorous, olfactory, taste, dan tactile/gustative. Berbeda dengan pendapat Laurie Babin (2010:17-49) yang menyebutkan sensory marketing dapat memberikan pengaruh kuat terhadap emosi dan ingatan pelanggan. Laurie Babin menyebutkan dimensi sensory marketing terdiri dari visual, audio, scent, taste, dan touch yang merupakan strategi perusahaan terhadap pelanggan yang dapat memberikan efek. Dimensi scent merupakan dimensi yang berpengaruh kuat terhadap emosi dan ingatan pelanggan terhadap brand.

Solomon (2011:84-92) memiliki pendapat tersendiri bahwa sensory marketing sangat dipengaruhi oleh dimensi sight, yang kemudian diikuti oleh dimensi lainnya yang merupakan pendukung dari dimensi sight. Solomon menyebutkan bahwa dimensi sensory marketing terdiri dari sight, sounds, smells, taste, dan textures/touch. Strategi sensory marketing menurut pendapat Solomon adalah strategi yang paling ideal untuk dilakukan dalam trend strategi oleh banyak perusahaan pada saat ini. Dari dimensi-dimensi menurut Solomon di atas terdapat ruang lingkup dari masing-masing dimensi seperti dimensi Sight yang memiliki ruang lingkup seperti: Color (warna), Size (model), Styling (model); Sounds dengan ruang lingkup: Voice (suara), Music (musik); Smells dengan ruang lingkup: Scent (wangi-wangian parfum), Fragrance (wangiwangian lembut), Odors (wangi-wangian yang nyaman); Taste dengan ruang lingkup: Flavor (rasa makanan); Textures/Touch dengan ruang lingkup: Skin (kulit), Feel (perasaan).

Berdasarkan ruang lingkup di atas, maka penelitian ini menganut pendapat Solomon (2011:84-92) yang menyatakan bahwa sensory marketing mencakup sight, sounds, smells, taste, dan textures/touch. Hal ini dikarenakan dimensi-dimensi tersebut sesuai dengan kondisi objek penelitian di lapangan sehingga diharapkan dapat memberikan informasi yang akurat terhadap sensasi yang dirasakan pelanggan. 


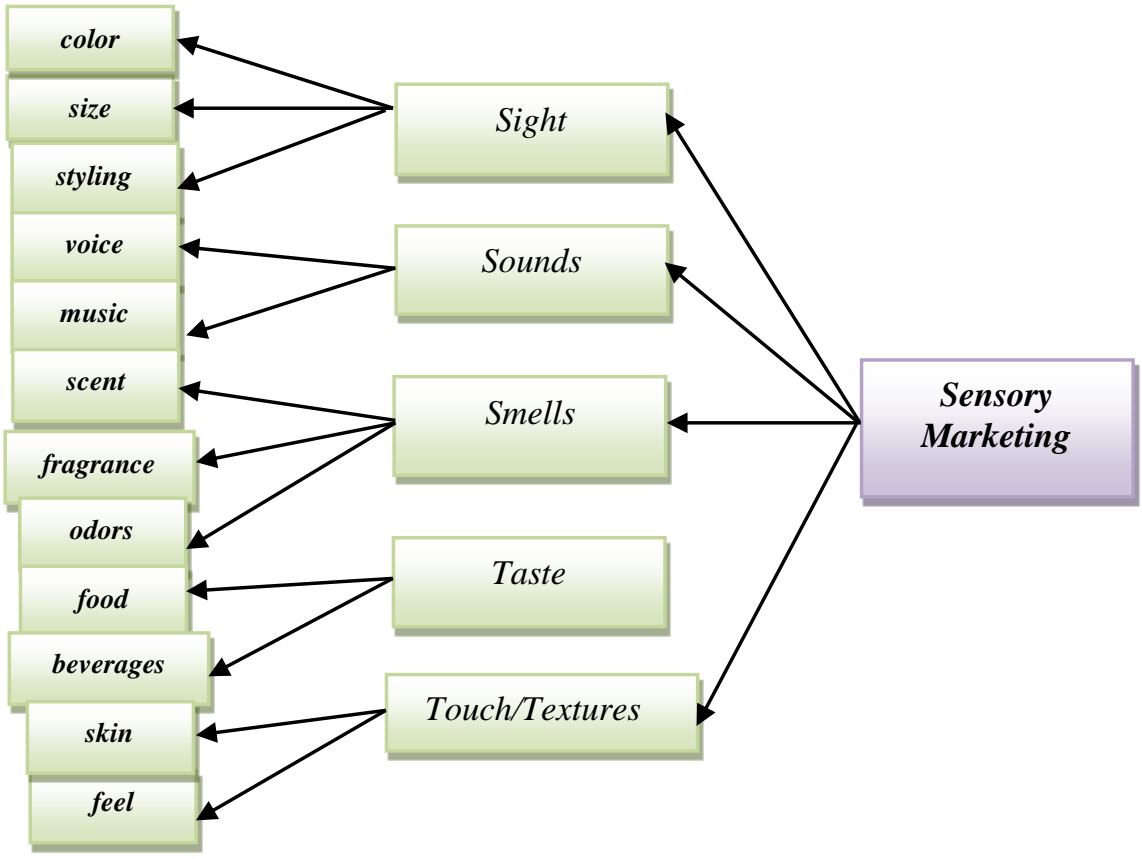

\section{GAMBAR 2.4 \\ PARADIGMA PENELITIAN \\ ANALISIS FAKTOR-FAKTOR SENSORY MARKETING \\ PADA MASKAPAI PENERBANGAN}

\subsection{Hipotesis}

Ulber Silalahi (2009:160) mengutarakan bahwa "Hipotesis merupakan pernyataan atau jawaban tentatif atas masalah dan kemudian hipotesis dapat diversifikasi hanya setelah hipotesis diuji secara empiris". Jadi, Hipotesis juga dapat dinyatakan sebagai jawaban teoritis terhadap rumusan masalah penelitian, belum merupakan jawaban yang empirik.

Peneliti menyusun hipotesis didukung oleh beberapa premis sebagai berikut:

1. Solomon (2011:654)

"Marketing strategies that focus on the impact of sensations on our product experiences".

2. Dipayan Biswas, Dhruv Grewal (Journal of marketing research 2010)

"Sensory aspects of both the mind and the body can motivate consumer to purchase and arouse their sense to have satisfaction".

3. Laura Oswald (Journal of Marketing Research 2009)

"Sensory marketing is another way of describing the form and function of all marketing communication, which aims to create awareness and influence consumer behaviour via the various sensory channels leading to the brain".

3. Samresearch.com 2009, P. Raghubir

"Sensory marketing is an effective tool in gaining sensory consumer insights for a marketing strategy. It measures and explains emotional consumer decisionmaking by variability of products, concepts, packaging, and marketing mix".

4. Hogskolan I Hamstald (Marketing Dissertation, 2008)

"Sensory marketing is defined as a way of measuring, and explaining consumer emotions to maximize product profitability"

5. American Marketing Association (2008) Sensory marketing: Marketing techniques that aim to seduce the consumer by using his senses to influence his feelings and behaviour".

6. Lena Goldkuhl, Maria Styvén, (European Journal of Marketing, Vol. 41, 2007) 
"By adding the component of sensing the scent, service providers have the opportunity to create a competitive advantage".

7. Stephan H. Haeckel, Lewis P. Karbone (Journal of Marketing Management , 2003:11)

"Emotional and sensory influenced by experience and guide through design a composite of clues that resonate with pelanggans and earn their satisfaction\&loyalty”.

8. J. Josko Brakus, Bernd H. Schmitt \& Lia Zarantonello (Journal of Marketing, 2009:15)

"customer experience is conceptualized as sensations, feelings, cognitions, and behavioral responses evoked by brandrelated stimuli".

9. Hochschild The Service Industries Journal (2009:103-116)

"Karyawan, dan fasilitas yang diberikan perusahaan akan membuat suatu nilai dalam pelayanan jasa dimana hal ini akan membangkitkan perasaan untuk menyampaikan pelayanan yang berhasil terhadap konsumen melalui panca indera (sensory).

10. Michael W. Allen, Richa Gupta, Arnaud Monier. (2006:4)

"Humans learn the relationship between a food and the consequences of its consumption. Positive sensory experiences result in positive food attitudes, thereby increasing consumption".

11. Tiger Johnston. (Journal of Consumer Research 2008)

"Physiopleasures are related to the body's sensory experiences and sociopleasures refer to the pleasures that people get from being together".

12. Shaw (159: 2007)

"As they search for competitive advantage, many airlines are making the cabin configuration more and more attractive. They are doing so by using new and costly seats, and also by giving substantially more space to each passenger".

13. Hulten, Broweus, Dan Van Dijk (2009:89-134)
"All contrasts, differences, and disturbances are caught by the sight sense".

Berdasarkan premis di atas, maka hipotesis penelitian adalah sebagai berikut: "Terdapat faktor yang paling dominan dari sensory marketing yang terdiri dari sight, sounds, smells, taste, dan touch/textures pada maskapai penerbangan the world's 4 star airlines (Survey pada Penumpang yang Pernah Menggunakan The World's 4 Star Airlines di Bandara Soekarno-Hatta).

\section{METODE PENELITIAN}

\subsection{Objek Penelitian}

Pendekatan ilmu yang digunakan dalam penelitian ini adalah ilmu manajemen pemasaran khususnya experiential marketing yang berkaitan dengan industri penerbangan khususnya faktor-faktor dari sensory marketing.

Penelitian ini dilakukan untuk menganalisis mengenai analisis konfirmatori sensory pada maskapai penerbangan the world's 4 star airlines di Bandara Soekarno-Hatta. Variabel yang diteliti adalah sensory marketing yang terdiri dari sight, sounds, smells, taste, dan touch/textures. Responden dalam penelitian ini adalah penumpang wisatawan mancanegara the world's 4 star airlines di Bandara Soekarno-Hatta.

\subsection{Metode Penelitian}

Metode merupakan cara kerja untuk mencapai suatu tujuan atau pendekatan yang dilakukan untuk mencapai suatu hal, metode merupakan cara kerja untuk mencapai suatu tujuan atau pendekatan yang dilakukan untuk mencapai suatu hal. Menurut Sugiyono (2010:2) yang dimaksud dengan metode penelitian adalah "cara ilmiah untuk mendapatkan data dengan tujuan dan kegunaaan tertentu". Data yang diperoleh melalui penelitian itu adalah data empiris yang mempunyai kriteria tertentu yaitu valid. Valid menunjukan derajat ketepatan antara data yang sesungguhnya terjadi pada obyek dengan data yang dikumpulkan oleh peneliti. 


\subsubsection{Jenis Penelitian dan Metode yang Digunakan}

Pada penelitian ini digunakan metode deskriptif dan verifikatif, menurut Malhotra (2009:100) menyebutkan bahwa "A type of conclusive research that has as its major objective the description of something-ussualy market characteristics or function". Sugiyono (2010:35) menjelaskan bahwa penelitian deskriptif adalah penelitian yang bertujuan memperoleh gambaran dari variabel penelitian. Melalui jenis penelitian deskriptif maka dapat diperoleh deskripsi mengenai confirmatory factor analysis sensory marketing pada maskapai penerbangan The World's 4 Star Airlines di Bandara Soekarno-Hatta.

Sifat pengujian verifikatif pada dasarnya ingin menguji kebenaran dari suatu hipotesis yang dilaksanakan melalui pengumpulan data di lapangan, penelitian ini menguji confirmatory factor analysis sensory marketing pada maskapai penerbangan The World's 4 Star Airlines.

Berdasarkan jenis penelitian di atas yaitu penelitian deskriptif dan verifikatif yang diaksanakan melalui pengumpulan data dilapangan, maka metode yang digunakan adalah explanatory survey. Menurut Sugiyono (2010:11):

Metode survei yaitu metode penelitian yang dilakukan pada populasi besar maupun kecil, tetapi data yang dipelajari adalah datadata dari sample yang diambil dari populasi tersebut, sehingga ditemukan kejadian- kejadian relatif, distribusi dan hubunganhubungan antar variabel sosiologis maupun psikologis.

Penelitian ini dilakukan pada kurun waktu tertentu, maka metode yang digunakan adalah cross section method (Husein Umar, 2003:43) adalah metode penelitian dengan cara mempelajari objek, dalam kurun waktu tertentu tidak berkesinambungan dalam jangka waktu panjang. Pada penelitian dengan menggunakan metode ini, informasi dari sebagian populasi dikumpulkan langsung ditempat kejadian secara empirik yaitu di Bandara Soekarno-Hatta dengan tujuan untuk mengetahui pendapat dari sebagian populasi terhadap objek yang sedang diteliti.

\subsubsection{Operasionalisasi Variabel}

Variabel yang akan dikaji dalam penelitian ini meliputi sensory marketing (X) yaitu strategi pemasaran untuk menciptakan sensasi yang dapat dirasakan langsung oleh panca indera manusia. Sub variabel sensory marketing terdiri dari sight $\left(\mathrm{X}_{1}\right)$, sounds $\left(\mathrm{X}_{2}\right)$, smells $\left(\mathrm{X}_{3}\right)$, taste $\left(\mathrm{X}_{4}\right)$, dan touch/texture $\left(\mathrm{X}_{5}\right)$. Secara lebih rinci operasionalisasi variabel dalam penelitian ini digambarkan dalam Tabel 3.1 sebagai berikut:

TABEL 3.1

OPERASIONALISASI VARIABEL

TABEL 3.1

OPERASIONALISASI VARIABEL PENELITIAN

\begin{tabular}{|c|l|l|l|l|c|}
\hline Variabel & \multicolumn{1}{|c|}{ Konsep Variabel } & Indikator & Ukuran & Skala & $\begin{array}{c}\text { No. Item } \\
\text { Pertanyaan }\end{array}$ \\
\hline $\begin{array}{c}\text { Sensory } \\
\text { Marketing } \\
(\mathrm{X})\end{array}$ & $\begin{array}{l}\text { Marketing strategies that } \\
\text { focus on the impact of } \\
\text { sensations } \text { on } \text { our product } \\
\text { experiences } \\
\text { Solomon (2011: } 654) .\end{array}$ & & & & \\
\hline
\end{tabular}




\begin{tabular}{|c|c|c|c|c|c|}
\hline $\operatorname{Sight}\left(\mathrm{X}_{1}\right)$ & $\begin{array}{l}\text { Salah satu variabel atau } \\
\text { dimensi sensory } \\
\text { marketing yang dapat } \\
\text { berpengaruh adalah Sight } \\
\text { (2011: 84). }\end{array}$ & $\begin{array}{l}\text { - Color } \\
\text { - Size }\end{array}$ & $\begin{array}{ll}\text { Inflight: } \\
\text { - } \quad \text { Tingkat kesesuaian warna } \\
\text { uniform. } \\
\text { - } \quad \text { Tingkat kemenarikan } \\
\text { warna seat. } \\
\text { - } \quad \text { Tingkat kemenarikan } \\
\text { warna toilet/restroom } \\
\text { Inflight: } \\
\text { - } \quad \text { Tingkat kesesuaian } \\
\text { ukuran tempat duduk } \\
\text { - Tingkat kesesuaian } \\
\text { ukuran luggage store } \\
\text { room. } \\
\text { - Tingkat Kesesuaian } \\
\text { ukuran aisle seat. } \\
\text { Tingkat kesesuaian } \\
\text { ukuran toilet/restroom. } \\
\\
\text { - } \\
\text { - Tinflight: } \\
\text { uniform Kesesuaian } \\
\text { Tingkat Kesesuaian } \\
\text { desain seragam room. } \\
\text { Tingkat kesesuaian } \\
\text { Display. }\end{array}$ & $\begin{array}{l}\text { - Ordinal } \\
\text { - Ordinal } \\
\text { - Ordinal } \\
\text { - Ordinal } \\
\text { - Ordinal } \\
\text { - Ordinal } \\
\text { - Ordinal } \\
\text { - Ordinal } \\
\text { - Ordinal }\end{array}$ & $\begin{array}{l}\text { C.I.4 } \\
\text { C.I.5 } \\
\text { C.I.6 } \\
\text { C.I.7 }\end{array}$ \\
\hline Sounds $\left(\mathrm{X}_{2}\right)$ & $\begin{array}{l}\text { Pelanggan telah dijejali } \\
\text { oleh musik dan suara, } \\
\text { akan tetapi sekarang } \\
\text { industri periklanan sangat } \\
\text { menyadari akan } \\
\text { pentingnya suara dan } \\
\text { musik. } \\
\text { Solomon (2011: 94). }\end{array}$ & - Music & $\begin{array}{l}\text { Inflight: } \\
\text { - } \quad \text { Tingkat Kenyamanan } \\
\text { noise reduction } \\
\\
\text { Inflight: } \\
\text { - } \quad \text { Tingkat Kejernihan noise } \\
\text { dari musik. } \\
\text { - } \text { Tingkat Kejernihan } \\
\text { terhadap headset yang } \\
\text { dipakai. } \\
\text { - } \quad \text { Tingkat Keragaman } \\
\text { pilihan musik. }\end{array}$ & $\begin{array}{l}\text { - Ordinal } \\
\text { - Ordinal } \\
\text { - Ordinal } \\
\text { - Ordinal }\end{array}$ & $\begin{array}{l}\text { C.II.12 } \\
\text { C.II.13 } \\
\text { C.II.14 }\end{array}$ \\
\hline
\end{tabular}




\begin{tabular}{|c|c|c|c|c|c|}
\hline Smells $\left(\mathrm{X}_{3}\right)$ & $\begin{array}{l}\text { Odors (wewangian) } \\
\text { mengendalikan atau } \\
\text { menbuat perasaan tenang, } \\
\text { dan menciptakan ingatan } \\
\text { atau dapat menghilangkan } \\
\text { stres. } \\
\text { Solomon }(2011: 89) .\end{array}$ & $\begin{array}{l}\text { - Scent } \\
\text { - Fragrance } \\
\text { - Odors }\end{array}$ & $\begin{array}{l}\text { Inflight: } \\
\text { - Tingkat Kesesuaian } \\
\text { wewangian parfum yang } \\
\text { dipakai cabin crew. } \\
\text { Inflight: } \\
\text { - Tingkat Kelembutan } \\
\text { wewangian di dalam } \\
\text { toilet. } \\
\text { - Tingkat Kelembutan } \\
\text { wewangian tissue yang } \\
\text { diberikan oleh airlines } \\
\text { crew. } \\
\text { Inflight: } \\
\text { Tingkat Kenyamanan } \\
\text { wewangian room selama } \\
\text { melakukan perjalanan. }\end{array}$ & $\begin{array}{l}\text { - Ordinal } \\
\text { - Ordinal } \\
\text { - Ordinal }\end{array}$ & $\begin{array}{l}\text { C.III.16 } \\
\text { C.III.17 }\end{array}$ \\
\hline Taste $\left(\mathrm{X}_{4}\right)$ & $\begin{array}{l}\text { Penerima rangsangan } \\
\text { (mulut) sangat mudah } \\
\text { merasakan rasa dan ikut } \\
\text { berperan dalam } \\
\text { pengalaman yang } \\
\text { didapatkan } \\
\text { Solomon }(2011: 93) .\end{array}$ & $\begin{array}{l}\text { Food \& } \\
\text { Beverages }\end{array}$ & $\begin{array}{l}\text { Inflight: } \\
\text { - Tingkat Kesesuaian } \\
\text { makanan yang tersedia di } \\
\text { pesawat. } \\
\text { - Tingkat Kesesuaian } \\
\text { minuman yang tersedia di } \\
\text { pesawat. }\end{array}$ & $\begin{array}{l}\text { - Ordinal } \\
\text { - Ordinal }\end{array}$ & $\begin{array}{l}\text { C.IV.19 } \\
\text { C.IV.20 }\end{array}$ \\
\hline $\begin{array}{c}\text { Textures/ } \\
\text { Touch }\left(\mathrm{X}_{5}\right)\end{array}$ & $\begin{array}{l}\text { Sentuhan (touch) dapat } \\
\text { mempengaruhi interaksi } \\
\text { penjualan Solomon } \\
(2011: 91) .\end{array}$ & $\begin{array}{l}\text { - Skin } \\
\text { - Feel }\end{array}$ & $\begin{array}{l}\text { Inflight: } \\
\text { • Tingkat Kualitas material } \\
\text { cover seat. } \\
\text { - Tingkat Kualitas reading } \\
\text { materials. } \\
\text { Inflight: } \\
\text { - Tingkat Kenyamanan } \\
\text { service dari cabin crew. } \\
\text { - Tingkat Kenyamanan } \\
\text { emotional sense pesawat } \\
\text { selama melakukan } \\
\text { perjalanan. }\end{array}$ & $\begin{array}{l}\text { - Ordinal } \\
\text { - Ordinal } \\
\text { - Ordinal } \\
\text { - Ordinal }\end{array}$ & $\begin{array}{l}\text { C.V.23 } \\
\text { C.V.24 }\end{array}$ \\
\hline
\end{tabular}

\subsubsection{Jenis dan Sumber Data}

Ulber Silalahi (2009:280) menyebutkan bahwa data diperoleh melalui suatu proses yang disebut pengumpulan data. Pengumpulan data dapat didefinisikan sebagai satu proses mendapatkan data empiris melalui responden dengan menggunakan metodemetode tertentu. Data merupakan bahan penting yang digunakan oleh peneliti untuk menjawab pertanyaan atau menguji hipotesis dan mencapai tujuan penelitian, oleh karena itu, data dan kualitas data merupakan pokok penting dalam penelitian karena menentukan kualitas hasil penelitian.

Istilah data menunjuk pada ukuran atau observasi aktual tentang hasil dari suatu investigasi survey, atau hasil observasi yang dicatat dan dikumpulkan, baik dalam bentuk angka ataupun jumlah dan bentuk kata-kata ataupun gambar. 
1. Sumber Data Primer

Ulber Silalahi

(2009:289)

mengatakan bahwa, data primer merupakan data yang dikumpulkan dari situasi aktual ketika peritiwa terjadi. Dalam penelitian ini, sumber data primer diperoleh dari respoden yang diwawancarai berdasarkan pertanyaan yang telah tersedia di dalam kuesioner. Penelit mewawancarai responden yang dianggap mewakili seluruh populasi dalam penelitian, yaitu penumpang wisatawan mancanegara di Bandara Soekarno-Hatta.

2. Sumber Data Sekunder

Ulber Silalahi

(2009:291)

berpendapat bahwa sumber data sekunder merupakan data yang dikumpulkan dari tangan kedua atau dari sumber-sumber lain yang telah tersedia sebelum penelitian dilakukan. Dalam penelitian ini, yang menjadi sumber data sekunder adalah berbagai literatur, artikel, karyakarya ilmiah, serta situs internet mengenai teori sensory marketing.

\subsubsection{Populasi, Sampel, dan Teknik Sampling}

\subsubsection{Populasi}

Malhotra (2009:369) “A population is the total of the elements that share some common set of characteristhics". Sugiyono (2010:80) mengungkapkan bahwa "Populasi adalah wilayah generalisasi yang terdiri atas obyek atau subyek yang mempunyai kualitas dan karakteristik tertentu yang ditetapkan oleh peneliti untuk dipelajari dan kemudian ditarik kesimpulannya". Sederhananya, Ulber Silalahi (2009:253) mengungkapkan bahwa "Populasi adalah seluruh unit-unit yang darinya sampel dipilih".

Penentuan populasi dalam penelitian ini adalah penumpang wisatawan mancanegara di Bandara Soekarno-Hatta pada tahun 2009. Penentuan populasi tersebut dilakukan sesuai dengan metode penelitian yang digunakan yaitu cross sectional method.

\subsubsection{Sampel}

Menurut Malhotra (2009:370) " $A$ sample is a subgroup of the population". Ulber Silalahi (2009:256) mengatakan memilih sampel secara tepat merupakan tahap sangat penting dalam mengadakan satu penelitian sebab kualitas sampel menentukan tingkat generalisasi tentang populasi.

Pada penelitian ini, penulis tidak meneliti seluruh populasi akan tetapi mengambil sampel yang representatif mengingat keterbatasan waktu, biaya, tenaga serta kompleksitas dari populasi Untuk menghitung sampel dilakukan dengan menggunakan rumus Slovin (Husein Umar, 2003:141) yaitu sebagai berikut:

$$
n=\frac{N}{1+N e^{2}}
$$

Keterangan

$n \quad=$ Ukuran Sampel

$N=$ Ukuran Populasi

$e=$ Kelonggaran ketidaktelitian karena kesalahan sampel yang dapat ditolerir

Perhitungan Rumus Slovin

$\mathrm{n} \quad=$ Sampel

$\mathrm{N}=1.195 .596$

e $=10 \%$

$$
\begin{aligned}
& n=\frac{N}{1+N e^{2}} \\
& n=\frac{1.195 .596}{1+1.195 .596 * 0.1^{2}} \\
& n=\frac{1.195 .596}{1+1.195 .596^{80.01}} \\
& n=\frac{1.195 .596}{11596,66}=99,99
\end{aligned}
$$

$n=99,99$ dibulatkan menjadi 100

Berdasarkan perhitungan di atas dengan menggunakan rumus Slovin dengan tingkat kelonggaran sebesar $10 \%$ maka diperoleh ukuran sampel (n) minimal sebesar 103, maka dalam penelitian ini sampel yang akan diambil berjumlah 100 penumpang wisatawan mancanegara The World's 4 Star Airlines.

\subsubsection{Teknik Sampling}

Sugiyono (2010:62) mengemukakan bahwa "Teknik sampling adalah merupakan teknik 
pengambilan sampel”. Maholtra (2009:373) berpendapat, "Nonprobability sampling relies on the personal judgement of the researcher, rather than chance, in selecting ellements. In probability sampling, elements are selected by chance, that is, randomly". Ulber Silalahi (2009:257) menyebutkan, pada dasarnya ada dua tipologi dari teknik pengambilan sampel yaitu probability sampling dan nonprobability sampling. Probability sampling meliputi sampling acak sederhana (simple random sampling), sampling sistematik (systematic sampling), sampling distratifikasi (stratified sampling), dan sampling bergugus (cluster sampling). Nonprobability sampling meliputi convenience sampling, judment sampling, quota sampling, dan snowball sampling.

Teknik sampling dalam penelitian ini menggunakan systematic sampling yang termasuk ke dalam probability sampling. Malhotra (2009:382) menyebutkan, "The sample is choosen by selecting a random starting point and then picking every it element in succession from the sampling frame". Ulber Silalahi (2009:264) berpendapat bahwa pemilihan sampel sistematis adalah teknik pemilihan sampel dari populasi yang dilakukan secara acak hanya untuk sampel yang pertama dari sejumlah sampel. Sedangkan untuk unsur-unsur sampel berikutnya dipilih secara sistematis.

Rancangan systematic sampling efektif digunakan sebagai pemilihan sampel jika populasi tersebut relatif besar, daftar dari elemen secara baik sekali tersedia, populasi memiliki pola beraturan, dan populasi bersifat homogen.

\subsubsection{Teknik Pengumpulan Data}

a. Observasi

b. Angket

c. Studi Literatur

\subsubsection{Hasil Pengujian Validitas dan Realibilitas}

Sugiyono (2010:348) mengutarakan bahwa "Instrumen yang valid bearti alat ukur yang digunakan untuk mendapatkan data itu valid. Valid berarti instrumen tersebut dapat digunakan untuk mengukur apa yang seharusnya diukur". Sedangkan Ulber Silalahi (2009:244) berpendapat bahwa:

Validitas adalah sejauhmana perbedaan dalam skor pada suatu instrumen (itemitem dan kategori respons yang diberikan kepada satu variabel khusus) mencerminkan kebenaran perbedaan antara individu-individu, kelompok-kelompok, atau situasi-situasi dalam karakteristik (variabel) yang diketemukan ukuran.

\subsubsection{Hasil Pengujian Validitas}

Pengujian validitas digunakan untuk memperhatikan relevansi dari sebuah instrumen guna mengetahui tujuan pembelajaran dan pertanyaan dari sebuah penelitian. Pengujian validitas dapat dilakukan dengan berbagai cara yaitu pengujian content validity, pengujian criterionrelated validity, dan construct validity. Jenis validitas yang digunakan dalam penelitian ini adalah pengujian validitas konstruksi (construct validity). Validitas konstruksi adalah penentuan validitas dengan cara mengkorelasikan antara skor yang diperoleh masing-masing item baik yang berupa pernyataan dengan skor totalnya, yang merupakan nilai yang diperoleh dari penjumlahan semua skor item. Korelasi antara skor item dengan skor totalnya harus signifikan berdasarkan ukuran statistik. Bila ternyata skor semua item berkorelasi dengan skor totalnya, maka dapat dikatakan bahwa alat ukur yang digunakan valid.

Perhitungan korelasi yang digunakan untuk pengujian validitas dalam penelitian ini adalah rumus korelasi product moment yang dikemukakan oleh Pearson. Berikut adalah rumus korelasi product moment :

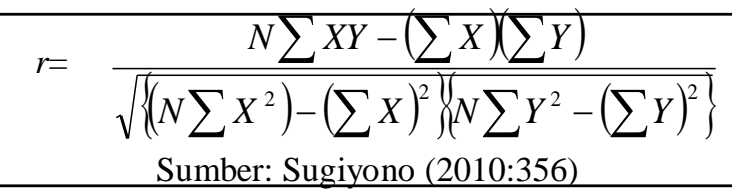

Keterangan :

$\mathrm{r} \quad=$ Koefisien validitas item yang dicari

$\mathrm{X}$ = Skor yang diperoleh subjek dari seluruh item

$\mathrm{Y}=$ Skor total

$\sum \mathrm{X}=$ Jumlah skor dalam distribusi $\mathrm{X}$

$\sum \mathrm{Y}=$ Jumlah skor dalam distribusi $\mathrm{Y}$

$\sum \mathrm{X}^{2}=$ Jumlah Kuadrat dalam skor distribusi $\mathrm{X}$

$\sum \mathrm{Y}^{2}=$ Jumlah Kuadrat dalam skor distribusi $\mathrm{Y}$

$10 \%$. Rumus uji t yang digunakan sebagai berikut : 


$$
\mathrm{t}=r \frac{\sqrt{n-2}}{\sqrt{1-r^{2}}} ; \mathrm{db}=\mathrm{n}-2
$$

Keputusan pengujian validitas item instrumen, adalah sebagai berikut:

1. Nilai $r$ dibandingkan dengan harga $\mathrm{r}_{\text {tabel }}$ dengan $\mathrm{dk}=\mathrm{n}-2$ dan taraf signifikansi $\alpha=0,01$

2. Item pertanyaan yang diteliti dikatakan valid jika $r_{\text {hitung }}>r_{\text {tabel }}$
3. Item pertanyaan yang diteliti dikatakan tidak valid jika $\mathrm{r}_{\text {hitung }}<\mathrm{r}_{\text {tabel }}$

Berdasarkan uji validitas yang dilakukan, didapat hasil pengujian yang dicantumkan pada Tabel 3.6 Pada tabel tersebut dinyatakan bahwa seluruh pertanyaan pada variabel sensory marketing dapat dilanjutkan untuk melakukan penelitian. Penyajian Tabel 3.6 sebagai berikut:

TABEL 3.6

HASIL PENGUJIAN VALIDITAS (SENSORY MARKETING

\begin{tabular}{|c|c|c|c|}
\hline Item Pertanyaan & $\boldsymbol{r}$ hitung & $\boldsymbol{r}$ tabel & keterangan \\
\hline \multicolumn{4}{|c|}{ SIGHT } \\
\hline \multicolumn{4}{|l|}{ Colour } \\
\hline \begin{tabular}{l|l} 
Uniform \\
\end{tabular} & 0.749 & 0.374 & Valid \\
\hline Seat & 0.396 & 0.374 & Valid \\
\hline \begin{tabular}{l|l} 
Toilet/Restroom \\
\end{tabular} & 0.693 & 0.374 & Valid \\
\hline \multicolumn{4}{|l|}{ Size } \\
\hline \begin{tabular}{l|l} 
Room \\
\end{tabular} & 0.586 & 0.374 & Valid \\
\hline Luggage & 0.744 & 0.374 & Valid \\
\hline Seat & 0.651 & 0.374 & Valid \\
\hline \begin{tabular}{|l|l} 
& Toilet/Restroom \\
\end{tabular} & 0.800 & 0.374 & Valid \\
\hline \multicolumn{4}{|l|}{ Style } \\
\hline Uniform & 0.551 & 0.374 & Valid \\
\hline Room & 0.575 & 0.374 & Valid \\
\hline Display & 0.431 & 0.374 & Valid \\
\hline \multicolumn{4}{|c|}{ SOUNDS } \\
\hline \multicolumn{4}{|l|}{ Voice } \\
\hline \begin{tabular}{l|l} 
& Noise Reduction \\
\end{tabular} & 0.760 & 0.374 & Valid \\
\hline \multicolumn{4}{|l|}{ Music } \\
\hline \begin{tabular}{l|l} 
Noise \\
\end{tabular} & 0.666 & 0.374 & Valid \\
\hline Headset & 0.749 & 0.374 & Valid \\
\hline Variation of Music & 0.396 & 0.374 & Valid \\
\hline \multicolumn{4}{|c|}{ SMELLS } \\
\hline \multicolumn{4}{|l|}{ Scent } \\
\hline \begin{tabular}{l|l} 
Crews \\
\end{tabular} & 0.693 & 0.374 & Valid \\
\hline \multicolumn{4}{|l|}{ Fragrance } \\
\hline \begin{tabular}{l|l} 
Toilet \\
\end{tabular} & 0.586 & 0.374 & Valid \\
\hline \begin{tabular}{l|l} 
Tissue \\
\end{tabular} & 0.744 & 0.374 & Valid \\
\hline \multicolumn{4}{|l|}{ Odors } \\
\hline \begin{tabular}{l|l} 
Room \\
\end{tabular} & 0.651 & 0.374 & Valid \\
\hline \multicolumn{4}{|c|}{ TASTE } \\
\hline \multicolumn{4}{|l|}{ Flavour } \\
\hline \begin{tabular}{l|l} 
Food \\
\end{tabular} & 0.800 & 0.374 & Valid \\
\hline Beverages & 0.551 & 0.374 & Valid \\
\hline \multicolumn{4}{|c|}{ TOUCH } \\
\hline \multicolumn{4}{|l|}{ Skin } \\
\hline Cover Seat & 0.575 & 0.374 & Valid \\
\hline \begin{tabular}{|l|l} 
Reading Materials \\
\end{tabular} & 0.749 & 0.374 & Valid \\
\hline \multicolumn{4}{|l|}{ Feel } \\
\hline Service & 0.760 & 0.374 & Valid \\
\hline Emotional Sense & 0.666 & 0.374 & Valid \\
\hline
\end{tabular}

Sumber: Pengolahan data 2011 


\subsubsection{Hasil Pengujian Reliabilitas}

Reliabilitas merupakan suatu ukuran yang menunjukkan bahwa suatu instrumen cukup dapat dipercaya untuk digunakan sebagai alat pengumpulan data karena instrumen tersebut sudah baik. Reliabilitas menunjukkan tingkat keterandalan tertentu. Pengujian reliabilitas instrumen dengan rentang skor atara 1-5 menggunakan rumus Cronbach alpha (Husein Umar, 2003:146) yaitu :

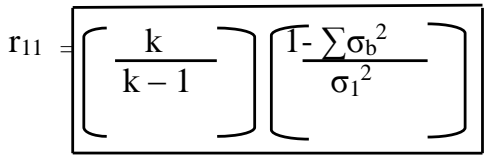

Keterangan:

r11 = Reliabilitas instrumen

$\mathrm{k}=$ Banyaknya butir pertanyaan

$\sigma_{1}^{2}=$ Varians total

$\sum \sigma_{b}^{2}=$ Jumlah varian butir

Jumlah varian butir dapat dicari dengan cara mencari nilai varians tiap butir, kemudian jumlahkan seperti berikut ini:

$\sigma=\frac{\sum x^{2\left(\Sigma / r^{2}\right)}}{n} / n$

(Husein Umar, 2003:147)

Ketentuan uji reliabilitas ditentukan dengan ketentuan sebagai berikut:

1. Jika koefisien internal seluruh item (ri) $\geq$ rtabel dengan tingkat signifikasi $5 \%$ maka item pertanyaan dikatakan reliabel.

2. Jika koefisien internal seluruh item (ri) > rtabel dengan tingkat signifikasi 5\% maka item pertanyaan dikatakan reliabel.

Perhitungan validitas dan reliabilitas pertanyaan dilakukan dengan bantuan program aplikasi SPSS 20.0 for window. Adapun langkah-langkah menggunakan SPSS 20.0 for window sebagai berikut:

1) Memasukkan data variabel $X$ dan $Y$ setiap item jawaban responden atas nomor item pada data view.

2) Klik variabel view, lalu isi kolom name dengan variabel-variabel penelitian (misalnya X, Y) width, decimal, label (isi dengan nama-nama atas variabel penelitian), coloum, align, (left, center, right, justify) dan isi juga kolom measure (skala: ordinal).

3) Kembali ke data view, lalu klik analyze pada toolbar pilih Reliability Analyze

4) Pindahkan variabel yang akan diuji atau klik Alpha, OK.

5) Akan dihasilkan output, apakah data tersebut valid serta reliabel atau tidak dengan membandingkan data hitung dengan data tabel. berikut:

Hasil pengujian reliabilitas sebagai

HASIL PENGUJIAN REALIBILITAS (SENSORY MARKETING)

\begin{tabular}{|l|l|l|l|}
\hline Variabel & $\begin{array}{c}\text { Alpha } \\
\text { cronbach }\end{array}$ & $\mathbf{r}_{\text {tabel }}$ & Kesimpulan \\
\hline $\begin{array}{c}\text { Sensory } \\
\text { Marketing }\end{array}$ & 0.938 & 0.374 & Reliable \\
\hline
\end{tabular}

Pada Tabel 3.7 dapat diketahui bahwa hasil tingkat reliability pada penelitian ini, untuk sensory marketing yaitu sebesar 0,938 .

\subsubsection{Rancangan Analisis Data dan Hipotesis}

\subsubsection{Analisis Data Deskriptif dan} Verifikatif

Penelitian ini menggunakan dua jenis analisis, yaitu analisis deskriptif khususnya bagi variabel yang bersifat kualitatif dan analisis kuantitatif berupa pengujian hipotesis dengan menggunakan uji statistik. Analisis deskriptif digunakan untuk melihat faktor penyebab, sedangkan analisis kuantitatif menitikberatkan dalam pengungkapan perilaku variabel penelitian. Dengan menggunakan kombinasi metode analisis tersebut dapat diperoleh generalisasi yang bersifat komperhensif dengan menggunakan SPSS 20.0 for windows. Analisis deskriptif digunakan untuk melihat faktor penyebab yang dalam penelitian ini analisis deskriptif untuk mengetahui kinerja sensory marketing yang terdiri dari sight, sounds, smells, taste, dan touch/textures the world's 4 star airlines.

\subsubsection{Analisis Verifikatif}

Alat penelitian yang digunakan dalam penelitian adalah angket kuesioner. Angket ini disusun oleh penulis berdasarkan variabel yang terdapat dalam penelitian, yaitu mengenai confirmatory factor analysis sensory marketing the world's 4 star airlines $\mathrm{di}$ Bandara Soekarno-Hatta.

Variabel yang diteliti adalah sensory marketing pada maskapai penerbangan dengan 
klasifikasi The World's 4 Star Airlines di Bandara Soekarno-Hatta, sehingga dalam penelitian ini akan meneliti Sensory Marketing

1. Method of Succesive Interval (MSI)

Penelitian ini menggunakan data ordinal oleh karena itu semua data ordinal terlebih dahulu ditransformasikan menjadi skala interval dengan menggunkan Method of Succesive Interval (Harun Al Rasyid, 1994:131). Langkah-langkah untuk melakukan tranformasi data tersebut adalah :

a. Menghitung frekuensi (f) setiap pilihan jawaban berdasarkan hasil jawaban responden pada setiap pertanyaan

b. Melakukan perhitungan proporsi (p) pada setiap pilihan jawaban dengan cara membagi frekuensi (f) dengan jumlah responden

c. Berdasarkan proporsi tersebut untuk setiap pertanyaan, hitung proporsi kumulatif untuk setiap pilihan jawaban

d. Untuk setiap pertanyaan, tentukan nilai batas Z (tabel normal) untuk setiap pilihan jawaban

e. Tentukan nilai interval rata-rata untuk setiap pilihan jawaban melalui persamaan berikut :

Scale $=($ Density at Lower Linear $)-($ Density at Upper Linear)

(Area Below Upper Linear) - (Area Below Lower Linear)

Data yang sudah berskala interval selanjutnya akan ditentukan data variabel independen dengan variabel dependen serta ditentukan persamaan yang berlaku untuk pasangan-pasangan tersebut.

1. Analisis Korelasi

Hubungan dua variabel terdiri dari hubungan positif dan hubungan negatif. Hubungan $\mathrm{X}$ dan $\mathrm{Y}$ dikatakan positif apabila kenaikan/penurunan $\mathrm{X}$ pada umumnya diikuti oleh kenaikan/penurunan $Y$. Ukuran yang digunakan untuk mengetahui kuat atau tidaknya hubungan X dan Y disebut koefisien korelasi (r). Nilai koefisien korelasi paling sedikit -1 dan paling besar $1(-1 \leq \mathrm{r} \leq 1)$, artinya jika :

- $\quad r=1$, hubungan $X$ dan Y sempurna dan positif (mendekati 1, hubungan sangat kuat dan positif)
- $\quad r=-1$, hubungan $X$ dan Y sempurna dan negatif (mendekati 1, hubungan sangat kuat dan negatif)

- $\quad r=0$, hubungan $X$ dan $Y$ lemah sekali atau tidak ada hubungan

Penelitian ini menggunakan koefisien korelasi Pearson's Product Moment. X dikatakan mempengaruhi $\mathrm{Y}$, jika berubahnya nilai $\mathrm{X}$ akan menyebabkan adanya perubahan nilai $Y$, artinya naik turunnya $X$ akan membuat nilai $Y$ juga naik turun. Dengan demikian nilai $Y$ ini akan bervariasi, namun variasi nilai $Y$ tersebut tidak semata-mata disebabkan oleh $\mathrm{X}$ karena masih ada faktor lain yang menjadi penyebab.

\subsubsection{Pengujian Hipotesis}

Teknik analisa data yang digunakan dalam penelitian ini adalah confirmatory factor analysis (analisis konfirmatori). Analisis konfirmatori digunakan untuk menentukan besarnya factor-faktor sensory marketing yang terdiri dari sight, sounds, smells, taste, dan touch/textures dan menentukan faktor yang paling dominan. Langkah-langkah dalam teknis analisis data confirmatory factor analysis adalah sebagai berikut:

1. Gambarkan Variabel dengan menggunakan Amos Graphics, tambahkan epsilon di setiap variabel

2. Setelah selesai klik kanan pada setiap variabel dan indikator

3. Pilih object properties, isi variable name dan variable lable sesuai dengan masing-masing variable.

4. Setelah semua selesai pilih select data file, lalu analysis properties, pilih output. Klik standardized estimates, squared multiples correlations, sample moments, text for normaly and outiers.

5. Kembali ke input lalu klik calculate estimates, setelah di proses klik view the output diagram. 


\section{Confirmatory factor analysis (CFA)}

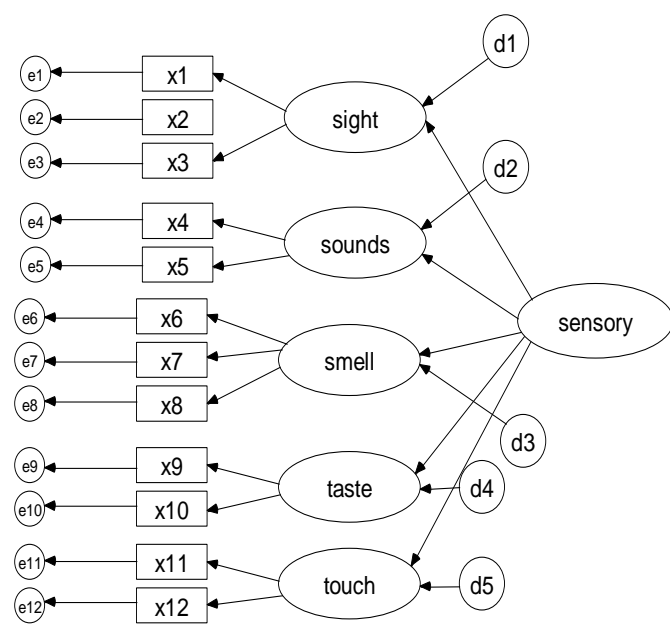

Sumber: Pengolahan data 2012

GAMBAR 3.1

\section{SUB STRUKTUR PENGUJIAN HIPOTESIS}

Keterangan:

$\mathrm{X} 1=$ colour

$\mathrm{X} 2=$ size

$\mathrm{X} 3$ = styling

$\mathrm{X} 4=$ voice

$\mathrm{X} 5=$ music

$\mathrm{X} 6=$ scent

$\mathrm{X} 7=$ fragrance

$\mathrm{X} 8=$ odors

$$
\begin{aligned}
& \mathrm{X} 9=\text { food } \\
& \mathrm{X} 10=\text { beverages } \\
& \mathrm{X} 11=\text { skin } \\
& \mathrm{X} 12=\text { feel } \\
& \text { e1-e12 = epsilon indikator } \\
& \text { d1-d5 = epsilon dimensi }
\end{aligned}
$$

Menghitung hasil estimasi parameter model pengukuran sensory marketing. Hasil Uji kebermaknaan terhadap masing-masing menjelaskan koefisien yang distandarkan menunjukkan angka di atas 0,40 dengan demikian seluruh koefisien tersebut dinyatakan signfikan pada taraf kesalahan 5\%. Artinya hal tersebut menunjukkan bahwa masing-masing dimensi dan indicator memiliki validitas yang memadai dalam mengukur sensory marketing.

$$
C R_{i}=\frac{\left(\sum_{i=1}^{n} \lambda_{i}\right)^{2}}{\left(\sum_{i=1}^{n} \lambda_{i}\right)^{2}+\left(\sum_{i=1}^{n} e_{i}\right)}
$$

Sejalan dengan itu Dilihat dari reliabilitas kontruk $(\mathrm{CR})>0.70$ baik dilihat dari dimensi atau indikator, artinya secara komposit dimensi atau indikator dalam model memiliki reliabilitas yang memadai.

IV. HASIL PENELITIAN DAN
PEMBAHASAN
4.1 Rekapitulasi Tanggapan Responden
Terhadap Sensory Marketing The
World's 4 Star Airlines

TABEL 4.19

\section{REKAPITULASI TANGGAPAN RESPONDEN TERHADAP SENSORY} MARKETING THE WORLD'S 4 STAR AIRLINES

\begin{tabular}{lllll}
\hline No & Sub Variabel/Dimensi & Total Skor & SKor Rata-rata & \% \\
\hline $\mathbf{1}$ & Sight & 5402 & 540.2 & 24.3 \\
$\mathbf{2}$ & Sounds & 1669 & 417.2 & 18.8 \\
$\mathbf{3}$ & Smells & 1675 & 418.7 & 18.9 \\
$\mathbf{4}$ & Taste & 834 & 417 & 18.8 \\
$\mathbf{5}$ & Touch/textures & 1688 & 422 & 19 \\
\multicolumn{7}{l}{ Total } & 10028 & 2215.1 & 100 \\
\hline
\end{tabular}

Sumber: Pengolahan Data 2012 
Berdasarkan Tabel 4.19 dapat terlihat bahwa penilaian sensory marketing di maskapai penerbangan The World's 4 Star Airlines yang mendapatkan pengaruh paling kuat yaitu pada sight dengan sub variabel colour, size, dan styling sebesar $24.3 \%$, hal ini karena apa yang terlihat dan dirasakan langsung oleh penumpang wisatawan mancanegara adalah dimensi sight. Dimensi yang mendapatkan penilaian sangat rendah adalah dimensi sounds yang terdiri dari voice dan music dengan indikator noise reduction, headseat, noise, dan variation of music, rendahnya penilaian ini karena pada dasarnya sounds merupakan kebutuhan sekunder bagi penumpang. Dimensi yang penilaian paling rendah lainnya adalah dimensi taste indikator food dan beverages sebesar $18.8 \%$, hal ini karena apa yang disediakan oleh The World's 4 Star Airlines (taste), penumpang tidak pasti akan merasa puas, taste seseorang sangat complicated dan tergantung suasana atau keinginan seseorang dalam suatu waktu.

\subsection{Pengaruh Faktor-Faktor Sensory Marketing Pada Maskapai Penerbangan The World's 4 Star Airlines.}

Pengujian hipotesis ini, dilakukan dengan menggunakan uji statistik Amos 5. Untuk mengetahui pengaruh sensory marketing yang terdiri dari sight $\left(\mathrm{X}_{1}\right)$, sounds $\left(\mathrm{X}_{2}\right)$, smells $\left(\mathrm{X}_{3}\right)$, taste $\left(\mathrm{X}_{4}\right)$, dan touch/textures $\left(\mathrm{X}_{5}\right)$, dilakukan dengan cara menganalisis pengaruh antar total skor item $\left(\mathrm{X}_{1}\right),\left(\mathrm{X}_{2}\right),\left(\mathrm{X}_{3}\right),\left(\mathrm{X}_{4}\right)$ dan $\left(\mathrm{X}_{5}\right)$.

Selanjutnya berdasarkan perhitungan statistik yang didasarkan pada angka-angka dari masing-masing variabel terlebih dahulu dilakukan transformasi, dimana dalam perhitungan transformasi dilakukan dengan program yang ada dalam SPSS Versi 20.0. Secara lengkap hasil pengolahan data pengaruh sensory marketing beserta lima sub variabelnya terhadap penumpang wisatawan mancanegara The World's 4
Star Airlines dengan analisis konfirmatori.

Analisis faktor konfirmatori yaitu suatu teknik analisis faktor di mana secara apriori berdasarkan teori dan konsep yang sudah diketahui dipahami atau ditentukan sebelumnya seperti faktor-faktor dari sensory marketing menurut Solomon (2006:8492), maka dibuat sejumlah faktor yang akan dibentuk, serta variabel apa saja yang termasuk ke dalam masing-masing faktor yang dibentuk dan sudah pasti tujuannya yang dapat dalam diagram berikut:

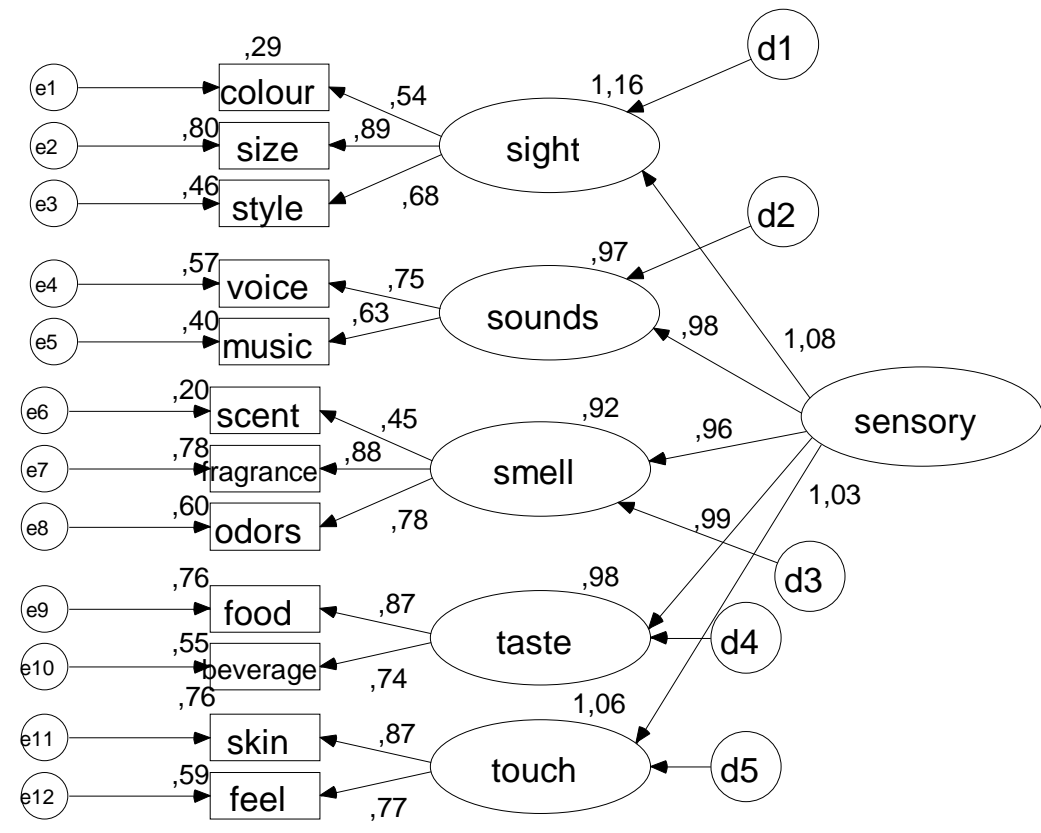

Sumber: Pengolahan data 2012

\section{GAMBAR 4.10 DIAGRAM PENGUJIAN HIPOTESIS}

Berdasarkan diagram, jalur pengujian hipotesis pada Gambar 4.11 maka dilakukan perhitungan analsis konfirmatori untuk mengetahui pengaruh faktor-faktor dimensi sensory marketing yang sesuai dengan Tabel 4.20 sebagai berikut: 
TABEL 4.20

HASIL ESTIMASI PARAMETER MODEL PENGUKURAN DIMENSI SENSORY MARKETING

\begin{tabular}{|c|c|c|c|c|c|c|c|c|}
\hline \multirow{2}{*}{$\begin{array}{l}\text { Persamaan } \\
\text { Pengukuran }\end{array}$} & \multicolumn{2}{|c|}{ Estimate } & \multirow[t]{2}{*}{ SE } & \multirow[t]{2}{*}{$\mathrm{Cr}$} & \multirow[t]{2}{*}{$\mathbf{P}$} & \multirow[t]{2}{*}{$\mathbf{R}^{2}$} & \multirow[t]{2}{*}{ Error } & \multirow[t]{2}{*}{ CR } \\
\hline & $\begin{array}{l}\text { Regression } \\
\text { Weights }\end{array}$ & $\begin{array}{l}\text { Standardized } \\
\text { Regression } \\
\text { Weights }\end{array}$ & & & & & & \\
\hline Smells & ,446 & ,959 &, 032 & 14,092 & $* * *$ & $\mathbf{0 , 9 1 9 6}$ & 0,0804 & 1,032 \\
\hline Touch & ,455 & 1,028 & ,039 & 11,806 & $* * *$ & & & 1,039 \\
\hline Taste & ,233 & ,991 & ,023 & 10,082 & $* * *$ & $\mathbf{0 , 9 8 2 0}$ & 0,0179 & 1,023 \\
\hline Sounds &, 448 & ,984 & ,059 & 7,544 & $* * *$ & $\mathbf{0 , 9 8 6 2}$ & 0,0317 & 1,059 \\
\hline Sight & 1,000 & 1,077 & & & & & & \\
\hline
\end{tabular}

Sumber: Penglahan Data 2012.

Hasil uji dari Tabel 4.20 menunjukkan bahwa dari semua uji kebermaknaan lebih dari 0.40 yang artinya seluruh koefisien sensory marketing yang diuji adalah signifikan dengan taraf kesalahan 5\%. Hasil pegujian tabel 4.20 memperlihatkan bahwa terdapat variabel sensory marketing the world's 4 star airlines yang paling dominan yaitu sight dengan bobot 1.077 (21.36\%) Hal tersebut sesuai dengan pernyataan Hulten, Broweus, Dan Van Dijk (2009:89-134) "All contrasts, differences, and disturbances are caught by the sight sense".

HASIL ESTIMASI PARAMETER MODEL PENGUKURAN

INDIKATOR SENSORY MARKETING

\begin{tabular}{|c|c|c|c|c|c|c|c|c|}
\hline \multirow{2}{*}{$\begin{array}{l}\text { Persamaan } \\
\text { Pengukuran }\end{array}$} & \multicolumn{2}{|c|}{ Estimate } & \multirow[t]{2}{*}{ SE } & \multirow[t]{2}{*}{$\mathrm{Cr}$} & \multirow[t]{2}{*}{$\mathbf{P}$} & \multirow[t]{2}{*}{$\mathbf{R}^{2}$} & \multirow[t]{2}{*}{ Error } & \multirow[t]{2}{*}{ CR } \\
\hline & $\begin{array}{l}\text { Regression } \\
\text { Weights }\end{array}$ & $\begin{array}{l}\text { Standardized } \\
\text { Regression } \\
\text { Weights }\end{array}$ & & & & & & \\
\hline $\mathrm{x} 1$ &, 385 &, 540 & ,060 & 6,438 & $* * *$ & 0,2916 & 0,7084 & 1,060 \\
\hline $\mathrm{x} 2$ & 1,000 & ,892 & & & & 0,7956 & 0,2043 & \\
\hline $\mathrm{x} 3$ &, 494 & 675 & ,057 & 8,692 & $* * *$ & 0,4556 & 0,5543 & $\mathbf{1 , 0 5 7}$ \\
\hline $\mathrm{x} 4$ &, 522 & ,753 & ,081 & 6,404 & $* * *$ & 0,5670 & 0,4329 & 1,081 \\
\hline $\mathrm{x} 5$ & 1,000 & 629 & & & & 0,3956 & 0,6043 & \\
\hline $\mathrm{x} 6$ &, 380 & ,452 & ,081 & 4,691 & $* * *$ & 0,2043 & 0,7956 & 1,081 \\
\hline $\mathrm{x} 7$ & 1,000 & ,883 & & & & 0,7796 & 0,2203 & \\
\hline $\mathrm{x} 8$ &, 539 & ,777 & ,055 & 9,775 & $* * *$ & 0,6037 & 0,3962 & 1,055 \\
\hline $\mathrm{x} 9$ & 1,152 & 874 &, 126 & 9,164 & $* * *$ & 0,7638 & 0,2361 & 1,126 \\
\hline $\mathrm{x} 10$ & 1,000 & ,741 & & & & 0,5490 & 0,4509 & \\
\hline $\mathrm{x} 11$ & 1,096 & 871 & , 109 & 10,083 & $* * *$ & 0,7586 & 0,2413 & 1,109 \\
\hline $\mathrm{x} 12$ & 1,000 & ,770 & & & & 0,5929 & 0,4071 & \\
\hline
\end{tabular}

Sumber: Pengolahan Data 2012.

Hasil uji dari Tabel 4.21 menunjukkan bahwa dari semua uji kebermaknaan lebih dari 0.40 yang artinya seluruh koefisien sensory marketing yang diuji adalah signifikan dengan taraf kesalahan 5\%. Hasil pegujian tabel 4.21 menunjukkan indikator yang paling dominan yang terdapat variabel sensory marketing the world's 4 star airlines yaitu indikator X2 (size) dengan bobot $0.892(10.07 \%)$ Hal tersebut sesuai dengan pendapat dari,

Shaw (159: 2007) yang menyebutkan:
"As they search for competitive advantage, many airlines are making the cabin configuration more and more attractive. They are doing so by using new and costly seats, and also by giving substantially more space to each passenger".

Seperti industri penerbangan pada umumnya mencari keunggulan bersaing, banyak maskapai penerbangan yang membuat konfigurasi kabin lebih atraktif lagi. Mereka 
nambah biaya seat yang baru, dengan tujuan untuk memberikan ukuran yang lebih bagi setiap penumpang.

\subsection{Implikasi Hasil Temuan Penelitian} 4.3.1 Temuan Penelitian Bersifat Teoritik

1. Berdasarkan hasil temuan penelitian penulis memperkuat sensory marketing yang dikemukakan oleh Solomon (2011:654) yang menyatakan bahwa lima dimensi dari sensory marketing yang terdiri dari sight, sounds, smells, taste, touch/textures sangat memiliki dampak terhadap sensasi dari pengalaman dari sebuah produk yang ditawarkan. "Marketing strategies that focus on the impact of sensations on our product experiences".

2. Sensory marketing pada The World's 4 Star Airlines memiliki pengaruh yang signifikan. Dengan demikian temuan penulis mengukuhkan premis yang dikemukakan oleh Hulten, Broweus, Dan Van Dijk (2009:89-134) untuk dimensi sight, dan pendapat Shaw (159: 2007) untuk indikator.

\subsubsection{Temuan Penelitian Bersifat Empirik}

1. Sensory marketing yang terdiri dari sight, sounds, smells, taste, touch/textures pada The World's 4 Star Airlines dalam meningkatkan kinerja sensory marketing. Berdasarkan faktor pembentuk tersebut, The kinerja World's 4 Star Airlines yang dipengaruhi paling tinggi (paling dominan) yaitu oleh dimensi sight dengan indikator size.

2. Berdasarkan temuan hasil penelitian tersebut, maka diyakini hasil penelitian yang mengukuhkan teori sebelumnya dan memodifikasi teori yang ada menjadi suatu penelitian yang memberikan pengaruh pada kinerja sensory marketing maskapai penerbangan The World's 4 Star Airlines, dan memperjelas bahwa sensory marketing merupakan faktor yang sangat efektif bagi suatu perusahaan khususnya maskapai penerbangan the world's 4 star airlines sebagai strategi yang sangat efektif dalam meningkatkan kinerja yang merupakan salah satu dari strategi pemasaran yang dilakukan oleh the world's 4 star airlines.

Tanggapan tamu Garden Permata Hotel terhadap keempat dimensi service encounter dengan sub variabel service encounter yang mendapatkan penilaian tertinggi yaitu spontaneity sebesar 29\%, hal ini menunjukan bahwa service encounter berupa spontaneity dirasakan oleh tamu sebagai hal yang paling benar-benar terasa selama tamu tersebut berada di lingkungan Garden Permata Hotel. Spontaneity merupakan aspek yang paling penting di dunia perhotelan, dimana kedekatan antara pelanggan dan karyawan terjadi karena adanya indikator-indikator dari spontaneity yang berupa pelayanan, komunikasi, responsiveness, dan pengalaman, yang akan menjadikan pelanggan untuk tetap membeli produk dan jasa yang ditawarkan karena pelanggan sudah merasa nyaman dan dekat dengan karyawan, sesuai dengan teori yang diungkapkan oleh Farida Jasfar (2009: 116) mengungkapkan "Pelayanan yang baik akan menghasilkan konsumen yang puas dan loyal yang dapat dijadikan aset masa depan".

\section{KESIMPULAN}

Berdasarkan hasil penelitian yang telah dilakukan dengan menggunakan analisis deskriptif dan verifikatif dengan menggunakan confirmatory factor analysis (CFA) faktorfaktor sensory marketing the world's 4 star airlines, maka berdasarkan penelitian tersebut dapat diambil kesimpulan sebagai berikut:

1. Gambaran secara umum tanggapan penumpang wisatawan mancanegara terhadap sensory marketing the world's 4 star airlines yang terdiri dari sight, sounds, smells, taste, touch/textures. mendapatkan respon yang baik. Pelaksanaan dari sensory marketing sudah dilaksanakan dengan baik, terbukti dengan tanggapan penumpang terhadap sensory marketing. Kontribusi terbesar dari dimensi sight dari lima dimensi lainnya, dengan indikator size dari total dua belas indikator the world's 4 star airlines.

2. Faktor-faktor pembentuk sensory marketing diurutkan dari pengaruh 
yang paling besar (dominan) untuk dimensi yaitu dari dimensi sight, touch/textures, taste, sounds, dan yang terakhir adalah smells. Kemudian untuk urutan indikator yang paling besar (dominan) yaitu mulai dari size, fragrance, food, skin, odors, feel, voice, beverages, styling, music, colour, dan yang terakhir adalah scent.

Berdasarkan hasil penelitian yang dilakukan, maka penulis merekomendasikan beberapa hal mengenai analisis konfirmatori sensory marketing pada maskapai penerbangan, yaitu:

1. The world's 4 star airlines diharapkan dapat terus menganalisis perkembangan sensory marketing yang telah diterapkan di dalam kabin (inflight), karena dengan grade the world's 4 star airlines harus dapat meningkatkan kinerja serta tetap memberikan suguhan yang lebih atraktif dan sensasi terhadap penumpang agar penumpang dapat puas dan menjadi loyal terhadap maskapai dengan mengikuti perkembangan yang semakin maju, dengan kata lain maaskapai the world's 4 star airlines tidak akan kalah bersaing dengan kompetitor lain dan menjadikan sensory marketing menjadi keunggulan yang menjadi perbedaan dengan maskapaimaskapai lainnya

2. Sebagai rekomendasi agar peneliti selanjutnya dapat mengkaji lebih luas mengenai strategi pemasaran yang dilakukan maskapai penerbangan the world's 4 star airlines, selain itu peneliti berharap dapat melakukan penelitian lanjutan yang dapat memberikan program maupun strategi yang dilakukan pihak maskapai penerbangan the world's 4 star airlines dan dapat bersaing dengan the world's 5 star airlines serta menjauhkan grade position antara The World's 4 Star Airlines dengan The World's 3 Star Airlines. Hal ini bertujuan agar The World's 4 Star Airlines dapat memberikan pelayanan yang lebih terhadap penumpang dan The World's 4 Star Airlines dapat memberikan yang terbaik kepada penumpangnya agar tercipta keberlangsungan, stabilitas, dan perkembangan secara continue dalam maskapai penerbangan the world's 4 star airlines.

\section{DAFTAR PUSTAKA}

Aaker, Jenifer. (2009). Research on The Sensuality of Products. Journal of Marketing Resarch.

Ali Hasan. (2008). Marketing. Medpress. Buku Kita: Jakarta.

Allen, Michael W., Gupta, Richa., Monier, Arnaud. (2006). The Interactive Effect of Cultural Symbols and Human Values on Taste Evaluation. Journal of Human Sensor Research. Sidney.

Andreani, Fransisca. (2007). Experiential Marketing (Sebuah Pendekatan Pemasaran). Jurnal Manajemen Pemasaran, Vol. 2, No. 1, April 2007: $1-8$

Babin, Laurie (2010), Emotional Marketing Components. Journal of Advertising.

Bernard T. Widjaja. (2009), Lifestyle Marketing: Paradigma baru pemasaran bisnis jasa. Gramedia Pustaka Utama: Jakarta.

Biswas, Dipayan \& Grewal, Dhruv. (2010). How to Order of Sampled Experiential Products Affects Choice. Journal of Marketing Research.

Bowie, David dan Buttle, Francis. (2004), Hospitality Marketing: an introduction. Elsevier. Amsterdam.

Brakus, J. Josko., Schmit, Bernd H. \& Zarantonello, Lia. (2009). Brand Experience: What is it? How is it Measured? Does it Effect Loyalty? Journal of Marketing.

Buchari, Alma. (2007), Manajemen Pemasaran dan Pemasaran Jasa. Alfabeta: Bandung

Fandy Tjiptono. (2009). Service Marketing. (Esensi \& Aplikasi). Markensis. Yogyakarta.

Goeldner, Charles R. \& Ritchie J.R. Brent. (2009). Tourism: principles, practicies, philosophies. John Whiley \& Sons Inc. New Jersey. USA.

Goldkulh, Lena \& Styvén, Maria. (2007). Sensing The Scent of Service Success. European Journal of Marketing. Vol. 41.

H. Oka Yoeti. (2005). Perencanaan Strategis Pariwisata. Daerah Tujuan Wisata. 
Haeckel, Stephan H. \& P. Karbone Lewis. (2003). How to Lead The Customer Experience. Journal of Marketing Management.

Hermawan Kertajaya. (2006). Boosting Loyalty Marketing Performance, Mizan. Indonesia.

Hochschild. (2009). How to Measuring Satisfaction. The Service Industries Journal.

Hulten, B., Broweus, N., and Dijk V. (2009), Sensory Marketing, Palgrave Macmillan. Hampshire, UK.

Husein Umar. (2003). Metode Riset Perilaku Organisasi. PT. Gramedia Pustaka Utama. Jakarta.

I Halmstald, Hogskolan. (2008). The Concept of Sensory Marketing:Marketing Disertation.

Johnston, Tiger. (2008). Evolutionary of Phsychology and Anthropology. Journal of Consumer Research.

Kahn. (2007), Sensory Branding. Kahn Consulting LLC.

Krishna, Aradhna. (2008). Research on the sensuality of product. Journal of Marketing.

..(2009). What is sensory marketing and why is it interesting and also important? Research on the sensuality of product. Journal of Marketing.

Kotler. P. and Keller, Kevin. (2009). Marketing Management. New Jersey. Pearson International Edition. Pearson Prentice Hall.

Lovelock Christopher dan Lauran Wirtz. (2011). Service Marketing $7^{\text {th }}$ ed. Pearson Hall. New Jersey.

Maholtra, Naresh K. (2009). Basic Marketing Research: a decision-making approach. Pearson Prentice Hall. New Jersey. USA.

Mustapha, Adli. Pei, Fong Jia. Peng, Lim Siaw. Hamid, Hamidah Abd. (2005). The Evaluation of Airline Service Quality Using The Analytic Hierarchy Process (AHP). Paper. Grand Plaza Parkroyal, Penang.

Oswald, Laura. (2009). Some Notes on Semiotics and Sensory Marketing. Journal of Marketing Research. .

Page, Stephen. (2007). Tourism Management. Managing for Change. Second Edition.
Buterworth-Heihnemann, Elsevier. Burlington. USA

Pine II Joseph B and Gilmore, James H. (1999). The Experience Economy. Massachussetts Harvard Business School Press: Boston.

Rieunier, S. (2009). Marketing Dissertation.

Shaw, Stephen. (2007). Airline Marketing Management. Sixth Edition. Ashgate. England.

Smilansky, Shaz. (2009) Experiential Marketing: A Practical Guide to Interactive Brand Experiences. Kogan Page. London and Philadelphia.

Solomon R. Michael. (2011). Consumer Behavior (buying, having, and being). Prentice Hall., New Jersey.

Sugiyono. (2010). Metode penelitian kuantitatif kualitatif dan R\&D. Alfabeta. Bandung.

Sugiyono. (2010). Statistika Untuk Penelitian. Alfabeta. Bandung.

Ulber Silalahi. (2009) . Metode Penelitian Sosial. Refika Aditama. Bandung.

Uma Sekaran., (2006), Statistik Penelitian, Jakarta

Zeithaml, V.A., M.J. Bitner. (2009), Service Marketing: Integrating Customer Focus Across the Firm, $5^{\text {th }}$ ed., Mc-Graw-Hill. Boston.

Website:

Raghubir, P. (2009). www. samresearch.com (Diakses pada Tanggal 10 Januari 2011)

www.unwto.org, UNWTO Highlight (Diakses pada tahun 2010,2011,2012)

www.airlinequality.com (Diakses pada tanggal 30 Juni 2012)

www.garuda-indonesia.com (Diakses pada tanggal 30 Juni 2012)

www.thaiairways.com (Diakses pada tanggal 30 Juni 2012)

www.evaair.com (Diakses pada tanggal 30 Juni 2012)

www.koreanair.com (Diakses pada tanggal 30 Juni 2012)

www.jal.com (Diakses pada tanggal 30 Juni 2012)

www.chinaairlines.com (Diakses pada tanggal 30 Juni 2012). 